\title{
Incomplete androgen insensitivity (Reifenstein syndrome) - a case report
}

\author{
inkomplet androjen insensitivitesi-reifenstein sendromu \\ Volkan Turan, Özgür Yeniel, Mete Ergenoğlu, Coşan Terek, Murat Ulukuş \\ Ege Üniversitesi Tip Fakültesi, Kadın Hastalıkları ve Doğum Anabilim Dall, İmir, Turkey
}

\section{Abstract}

We report a 20 year old case of partial androgen insensitivity syndrome, referred to our clinic with complaints concerning external genital organs and left undescended testicle. The phenotypically male case was first evaluated for secondary sex development. Axillary hair was scanty and no pubic hair was found. There was no breast development. In the gynecological examination, the clitoris was hypertrophic $(4.6 \mathrm{~cm})$ and a blind vagina with intact hymen was seen. Abdominopelvic ultrasonography revealed the absence of an uterus and adnexes which was supported by magnetic resonance imaging (MRI). There was a palpable mass in the left inguinal canal (cryptorchism), seen as atrophic tissue under the skin in MRI. Although the other testis was in the labioscrotal fold, it was atrophic. The Karyotype was 46 $\mathrm{XY}$ after genetic investigation.

(J Turkish-German Gynecol Assoc 2010; 11: 110-2)

Key words: Reifenstein syndrome, testicular malignancy

Received: 5 October, 2009

Accepted: 3 November, 2009

\section{Case report}

A 20-year-old boy was referred to our clinic with complaints concerning the external genital organs and left undescended testicle. He was raised as a girl up to the age of 17 . The phenotypically male case was first evaluated for secondary sex development. Axillary hair was scanty and no pubic hair was found. There was no breast development. In the gynecological examination, the clitoris was hypertrophic. $(4.6 \mathrm{~cm})$, a blind vagina with intact hymen and also perineal hypospadias was seen. Abdominopelvic ultrasonography revealed the absence of an uterus and adnexes which was supported by magnetic resonance imaging. There was a palpable mass in the left inguinal canal (cryptorchism) which was seen as atrophic tissue under the skin in MRI. Although the right testis was in thelabioscrotal fold it was atrophic (Figure 1). Human chorionic gonadotropin, alfa fetoprotein (AFP) and lactate dehydrogenase (LDH) levels were detected for the risk of cancer which is associated with testicular tissue. $(0.01 \mathrm{mlU} /$ $\mathrm{ml}, 3.85 \mathrm{ng} / \mathrm{ml}, 299 \mathrm{U} / \mathrm{l}$ respectively) All values were normal. The reactivity of $5 \alpha$ reductase and $21 \alpha$ hydroxylase were also

\section{Özet}

Yirmi yaşında erkek fenotipli hasta, polikliniğimize dış genital organlardaki farkllık ve sol inguinal bölgede ele gelen kitle şikayetiyle başvurdu. Olgu ilk olarak sekonder sex karekterleri açısından değerlendirildi. Pubik kıllanma olmamasına karşın seyrek aksiller kıllanma mevcuttu. Meme gelişimi yoktu. Jinekolojik muayenede hipertrofik klitoris $(4.6 \mathrm{~cm})$, intakt hymen ve kör vajen saptand. Abdominopelvik ultrasonda uterus ve adneksler izlenmedi. Bunun üzerine hastaya MR çekildi ve sol inguinal bölgede kriptorşizm ile uyumlu testiküler doku cilt altında atrofik olarak izlendi. Diğer testis ise labioskrotal foldun içinde olup, atrofikti. Genetik inceleme yapıldı, karyotip 46 XY olarak saptandl.

(J Turkish-German Gynecol Assoc 2010; 11: 110-2)

Anahtar kelimeler: Reifenstein sendromu, testiküler malignite

Geliş Tarihi: 05 Ekim 2009

Kabul Tarihi: 03 Kasım 2009 normal. Follicle stimulating hormone (FSH), luteinizing hormone (LH) and free testesterone levels were high.(36.01 mlU/ $\mathrm{ml}, 13.92 \mathrm{mlU} / \mathrm{ml}, 10.3 \mathrm{pg} / \mathrm{ml}$ respectively) Other androgens, 17- hydroxyprogesterone and cortisol levels were normal. Karyotype was determined as $46 \mathrm{XY}$ on chromosomal analysis. The patient had undergone inguinal herniotomy five years earlier and had an penoscrotal hypospadias reparation two years earlier. There was no familial history of ambiguity.

\section{Introduction}

Congenital genital anomalies are very complex pathologies. The androgen insensitivity syndrome (AIS) is an X-linked disorder which can be seen in 46XY individuals with normal androgen production and metabolism. AIS is estimated to be present in 1: 20,000-64,000 male births $(1,2)$, and variable phenotypic expression has allowed the classification of AIS into complete (CAIS) and partial forms (PAIS). PAIS is the most common form. Partial androgen insensitivity syndrome (PAIS) includes syndromes that were once thought to represent separate entities: Reifenstein, Gilbert-Dreyfus, Rosewater 
and Lub syndromes. In the differential diagnosis of AIS, congenital adrenal hyperplasia and $5 \alpha$-reductase deficiency must be considered. In the present report, we describe a case who is 20 years-old, and presented at our polyclinic with complaints concerning the external genitalia and an undescended testicle, diagnosed after a thorough investigation (establishment of karyotype, investigation of hormones and their derivates and radiological examination) as PAIS similar to Reifenstein syndrome.

\section{Case report}

A 20-year-old boy was referred to our clinic with complaints concerning his external genital organs and left undescended testicle. He was raised as a girl until the age of 17. The phenotypically male case was first evaluated for secondary sex development. Axillary hair was scanty and no pubic hair was found. There was no breast development. In the gynecological examination, the clitoris was hypertrophic. $(4.6 \mathrm{~cm})$, a blind vagina with intact hymen and also perineal hypospadias was seen. Abdominopelvic ultrasonography revealed the absence of uterus and adnexes and was supported by magnetic resonance imaging. There was a palpable mass in the left inguinal canal (cryptorchism) which was seen as atrophic tissue under the skin in MRI. Although the right testis was in the labioscrotal fold it was atrophic. (Figure 1) Human chorionic gonadotropin, alfa fetoprotein (AFP) and lactate dehydrogenase (LDH) levels were detected for the risk of cancer associated with testicular tissue. ( $0.01 \mathrm{mlU} / \mathrm{ml}, 3.85 \mathrm{ng} / \mathrm{ml}, 299 \mathrm{U} / \mathrm{l}$ respectively) All the values were normal. The reactivity of $5 \alpha$ reductase and $21 \alpha$ hydroxylase were normal also. Follicle stimulating hormone (FSH), luteinizing hormone ( $\mathrm{LH}$ ) and free testesterone levels were high. (36.01 $\mathrm{mlU} / \mathrm{ml}, 13.92 \mathrm{mlU} / \mathrm{ml}, 10.3 \mathrm{pg} / \mathrm{ml}$ respectively) Other androgens, 17- hydroxyprogesterone and cortisol levels were normal.The Karyotype was determined as $46 \mathrm{XY}$ on chromosomal analysis. He had undergone inguinal herniotomy five years earlier and had had a penoscrotal hypospadias reparation two years earlier. There was no familial history of ambiguity.

\section{Discussion}

Diagnosis is usually established either during inguinal herniotomy or application of a patient at puberty with absence of menstruation. During the definition of genital ambiguity, it is important to assess nutritional status, arterial blood pressure, the presence of pubic hair, acne and signs of puberty. External genitalia should be assessed to classify the degree of virilization, analyze the size of the phallus, position of the urethral meatus, presence of vaginal introitus or urogenital sinus opening, degree of fusion, symmetry and wrinkling of the labioscrotal folds, presence of inguinal masses and location and size of the gonads. Hormonal tests and karyotyping should be performed at specialist services, as should be the imaging of the uterus, gonads, prostate and urogenital sinus, which is necessary, but not always conclusive. The most frequently used studies are

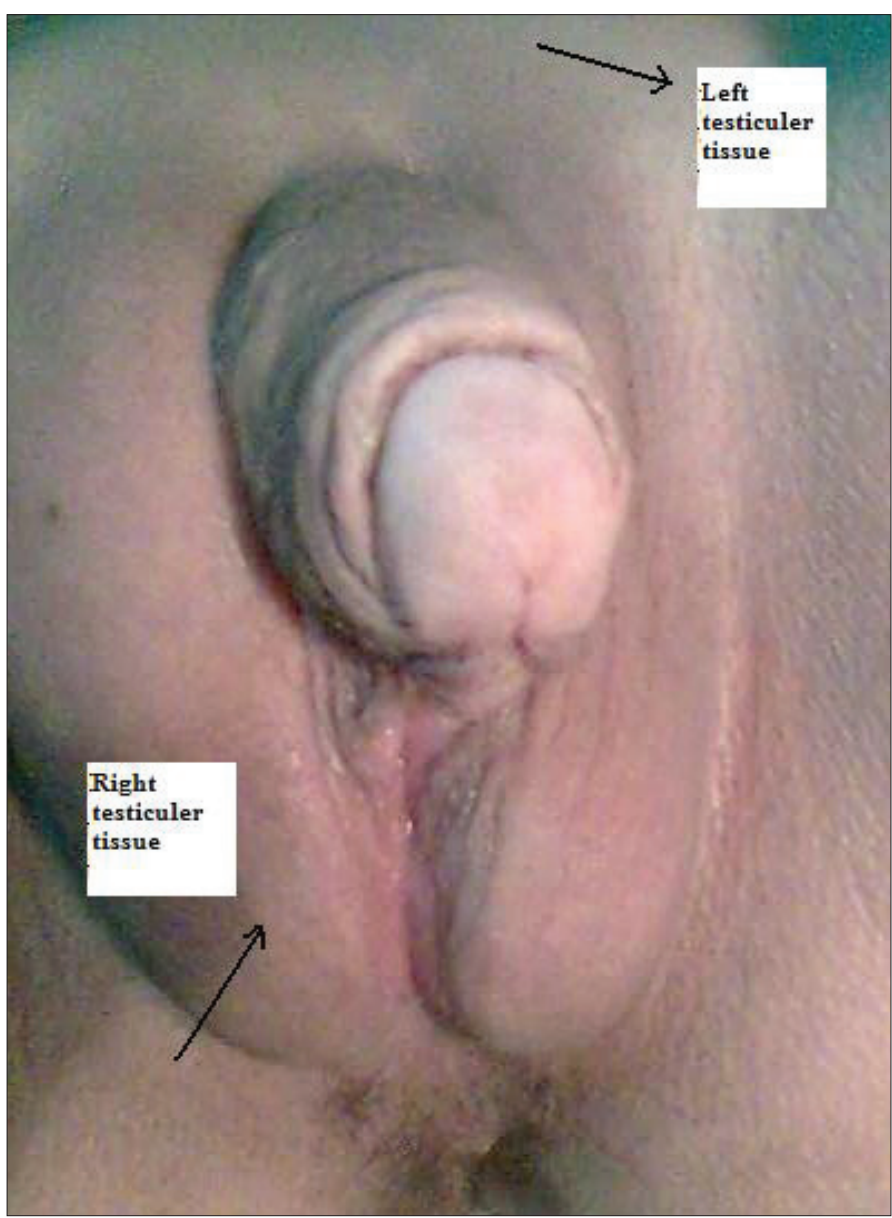

Figure 1. The sites of testicular tissues

ultrasound in association with genitourinary imaging and, less frequently, computerized tomography or magnetic resonance imaging of the pelvic region. During the radiologic examination urinary system anomalies should be considered.

The most frequent cause of virilization (around 80 to $90 \%$ of cases) with female genetic gender $(46, \mathrm{XX})$ is congenital adrenal hyperplasia. It can manifest in two clinical forms, simple virilization (SV) or a salt wasting form (SW). The SV form accounts for 20 to $30 \%$ of cases and causes ambiguous genitalia in female newborn infants. When untreated, it leads to progressive postnatal virilization in both sexes, with signs and symptoms of early pseudopuberty. In the SW form, the clinical manifestations include, in addition to the prenatal virilization of females and postnatal virilization of both sexes, a range of forms, from the severe cases of hyponatremic and hyperkalemic dehydration, vomiting, metabolic acidosis, hypovolemic shock and death, if treatment is not given. If the genetic gender is male, the diagnosis can be $5 \alpha$-reductase deficiency or androgen insensitivity syndrome (AIS). With $5 \alpha$-reductase deficiency there is genital virilization, although not always with adequate penile growth, absence of gynecomastia and hypoplasia or absence of the prostate. Thus, in this situation a genetically $46 \mathrm{XY}$ individual has more female features. On considering the types of AIS, Baron (3) reported that in the CAIS there was absent or very scarce 
pubic hair in $100 \%$ of the cases, normal development of breasts in $97 \%$ of the cases, blind vagina of mean length $5.0+/-2.3 \mathrm{~cm}$ in $97 \%$ of the cases and inguinal hernia in $30 \%$ of the cases. In PAIS, normal breasts occured in $62.5 \%$, public hair in $50 \%$, complete absence of vagina in $62.5 \%$, blind vagina of mean length $2.5 \mathrm{~cm}$ in $37.5 \%$, inguinal hernia in $75 \%$ and hypertrophy of clitoris of mean length $2.0+/-1.0 \mathrm{~cm}$ in $62.5 \%$ of the cases. In the incomplete form, surgery for inguinal hernia was necessaryin $87.5 \%$ of the patients (studied in 41 AIS patient). Our patient 's external genitalia exhibits hypertrophic clitoris, perineal hypospadias and cryptorchism, also called Reifenstein syndrome.

Ahmed et al. (4) compared children, known as AIS, to the sex of rearing from birth. The median mascularization score was used for this. The median masculinization score of 3 was higher in the group reared as boys than in the group of girls, who had a median masculinization score of 2.5. However, there was no significant difference between the scores on analysis. Although the present case was raised as a girl, after 17 years he has feelings and attitudes of a male and his masculinization score is 4 (Table 1).

A common practice is to remove the testes after puberty when feminization of the affected individual is complete, since feminization occurs partly by testicular estrogen and partly by peripheral conversion of androgen to estrogen. The reason for the postpubertal gonadectomy is the risk of testicular malignancy, which rarely occurs before puberty. The malignant development may first be carcinoma in situ, later gonadoblastoma, which if untreated may develop into malignant germinoma or

Table 1. Criteria for the masculinization score

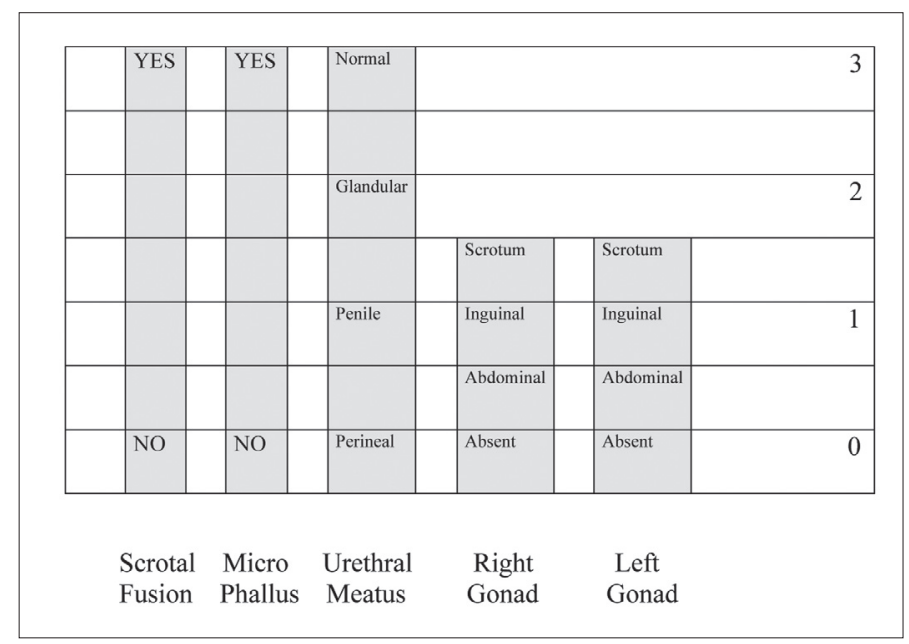

seminoma (5). Although our patient has normal markers for testicular malignancy, absolute testicular tissue must be extirpated with an operation. Because of this we referred him to an urology doctor for testicular tissue extirpation.

At present more than 100 mutations at the androgen receptor gene are known (6). The incomplete forms are more common but also more difficult to diagnose. The appearance of those individuals might range from almost normal female to nearly male. Early and correct diagnosis requires adequate medical attention in order to make it possible to establish prognosis of puberty, fertility and malignancy. This reduces the risk of psychological and social problems. Depending on their age and ability to understand, the patient can contribute to defining their own sex. The sex of rearing depends on genetic and physiologic criteria and on the prognosis of life quality in the future. Surgical and medical treatment is applied to emphasize or encourage the development of the appropriate sex features, attempting to avoid anatomical discrepancy and helping to confirm psychological identity.

\section{Conflict of interest}

There is no conflict of interest

\section{References}

1. Isurugi $\mathrm{K}$, Hasegawa F, Shibahara $\mathrm{N}$, Mori $\mathrm{H}$, Shima $\mathrm{H}$, Harada $\mathrm{N}$, et al. Incomplete testicular feminization syndrome: studies on androgen receptor (AR) function, AR gene analysis, and aromatase activities at puberty and long-term observations of clinical and hormonal features from infancy to puberty. Endocr J. 1996; 43: 557-64.

2. Hashmi A, Hanif F, Hanif SM, Abdullah FE, Shamim MS. Complete Androgen Insensitivity Syndrome1: J Coll Physicians Surg Pak. 2008; 18: 442-4.

3. Baron J. Classical and incomplete androgen insensitivity syndromes. [Article in Polish]1: Ginekol Pol. 1994; 65: 377-86.

4. Ahmed SF, Cheng A, Dovey L, Hawkins JR, Martin H, Rowland J. et al Phenotypic Features, Androgen Receptor Binding, and Mutational Analysis in 278 Clinical Cases Reported as Androgen Insensitivity Syndrome The Journal of Clinical Endocrinology \& Metabolism 2000 Vol. 85: 658-65.

5. Chavhan GB, Parra DA, Oudjhane K, Miller SF, Babyn PS, Pippi Salle FL. Imaging of ambiguous genitalia: classification and diagnostic approach Radiographics. 2008; 28: 1891-904.

6. Zaparackaite I, Barauskas V. Congenital genital anomalies. Aspects of diagnostics and treatment; Medicina (2003) Vol. 39, No. 2: 105-13. 